\title{
Poor cousin who came to stay: The well-established Mirror and the depression-era launch of the New Zealand Woman's Weekly
}

Gavin Ellis

Keywords \# New Zealand Woman's Weekly \# the Mirror \# women's magazine market \# depression-era magazines \# feminine identity This article places the New Zealand Woman's Weekly magazine within the processes of change that were occurring in the years following the First World War when perceptions of the roles of women were changing and domestic consumerism was evolving. It contrasts the first issue of the magazine, launched on 8 December 1932, with that month's edition of New Zealand's largest selling home journal, the Mirror, to illustrate how its founders had identified a gap in the depression-era market in spite of their meagre resources.

A frisson of fear must have passed through the owners of the New 

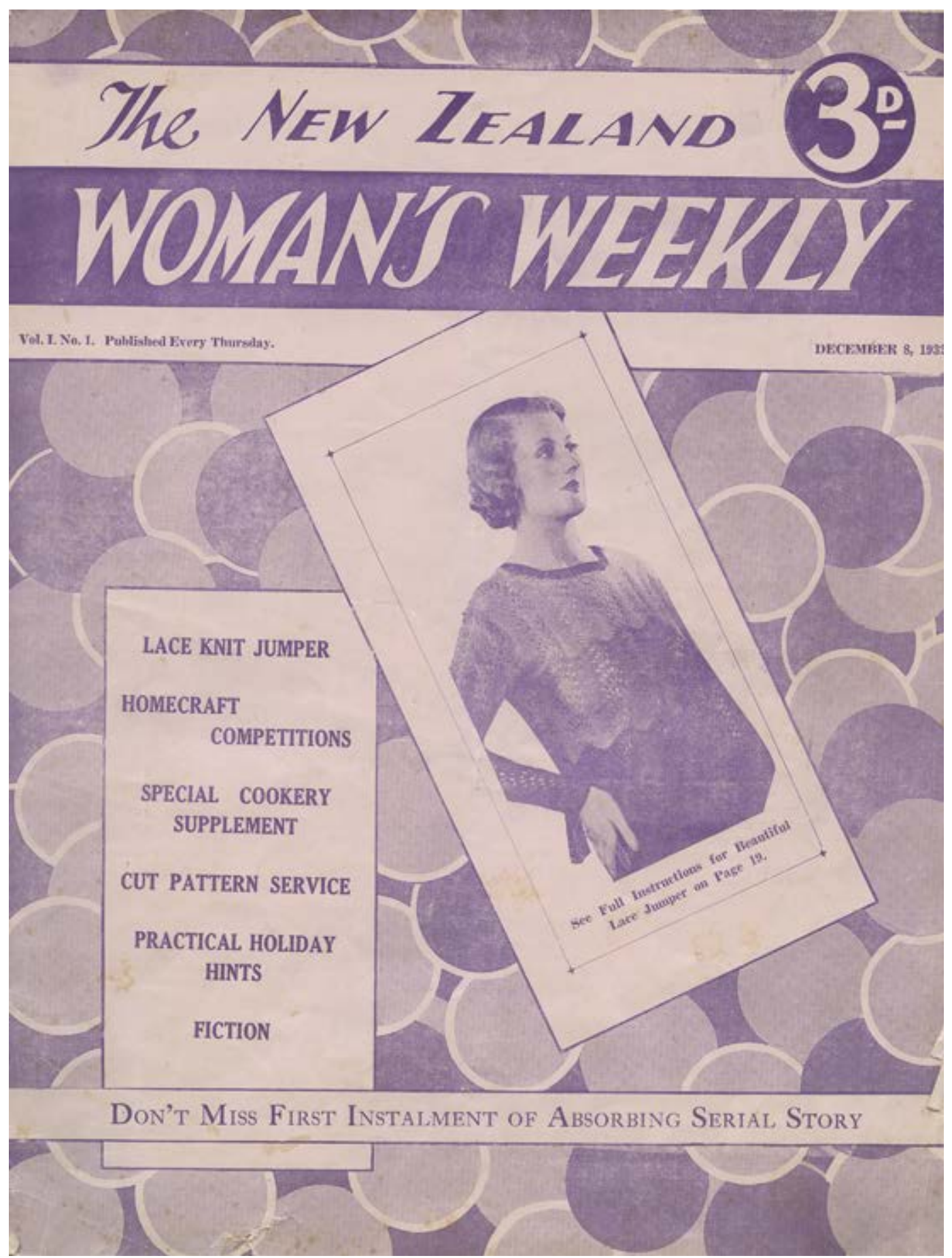
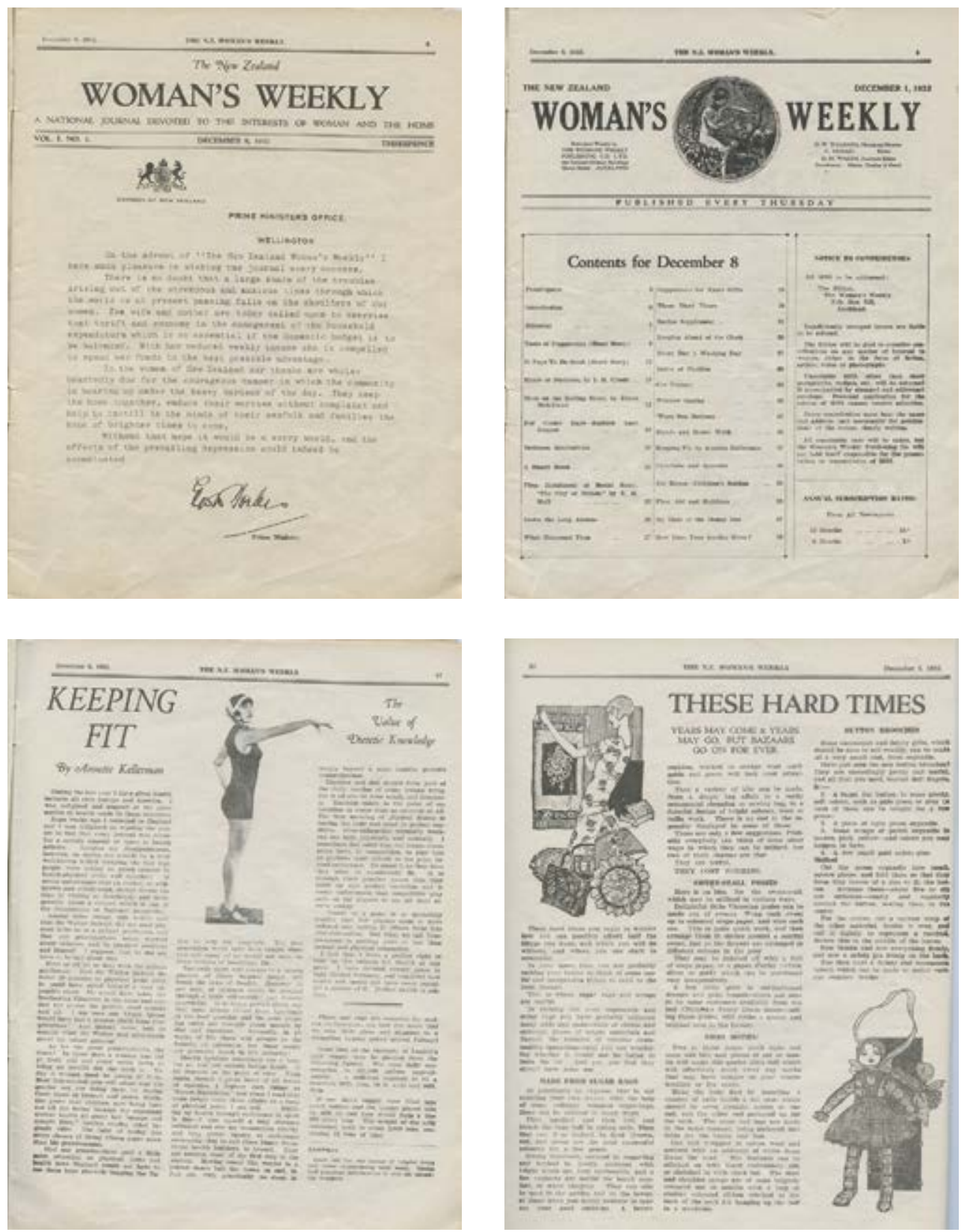

New Zealand Woman's Weekly

The Woman's Weekly first appeared in 1932 but became synonymous with its editor, Jean Wishart, who led the magazine from 1952 to 1985 . Circulation peaked at 250,000 in 1983 although the issue covering the marriage of Prince Charles and Diana Spencer was a sell-out at 300,000 copies. In 1988 the magazine, along with the New Zealand Listener, was sold by New Zealand News (publisher of the Auckland Star) to Wilson \& Horton (publisher of the New Zealand Herald). In 2014, it became part of the stable of magazines published in New Zealand by the German-owned Bauer Group. The magazine has an emphasis on celebrity news and in March 2017 had an audited circulation slightly below 50,000 copies. 


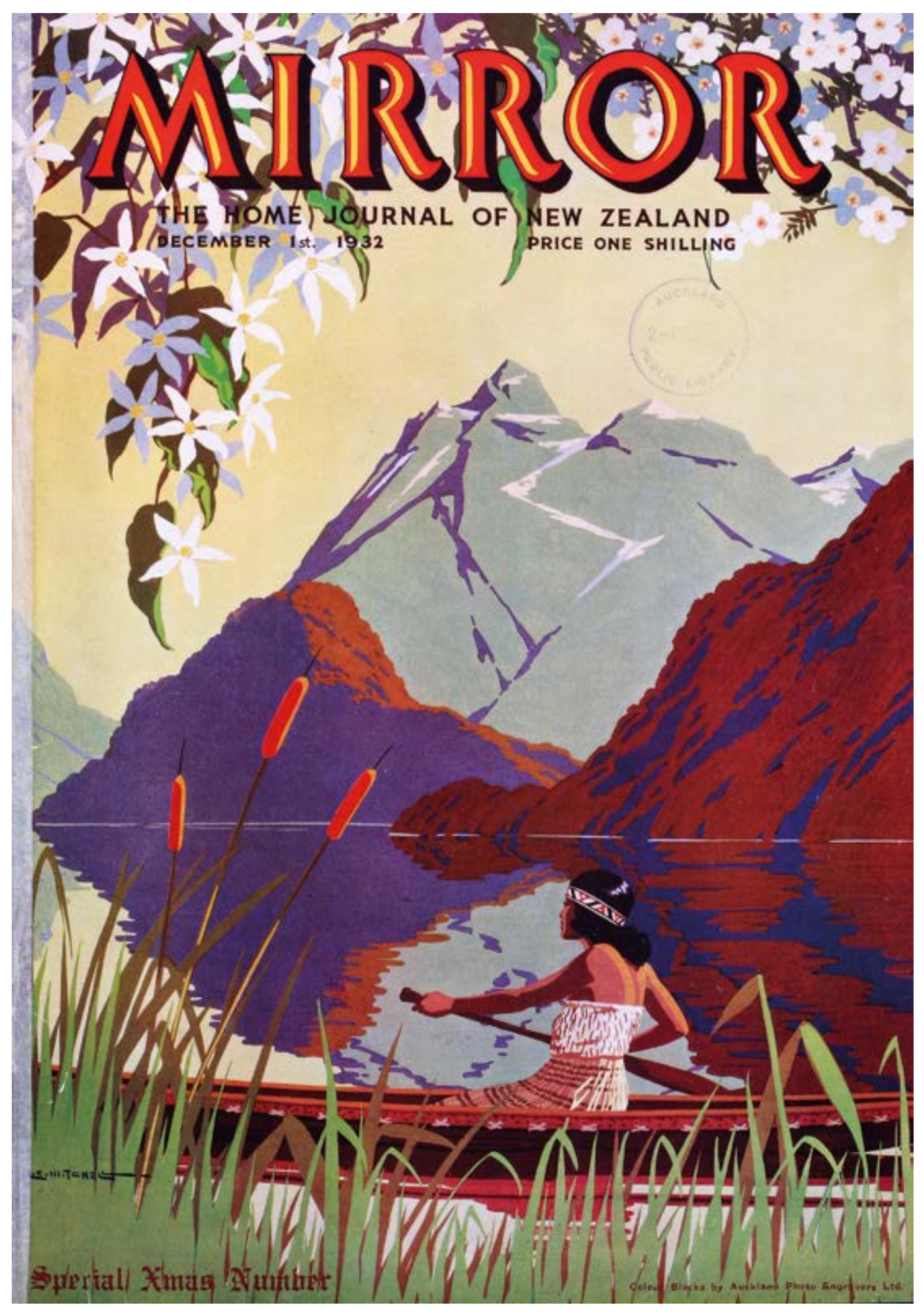

48

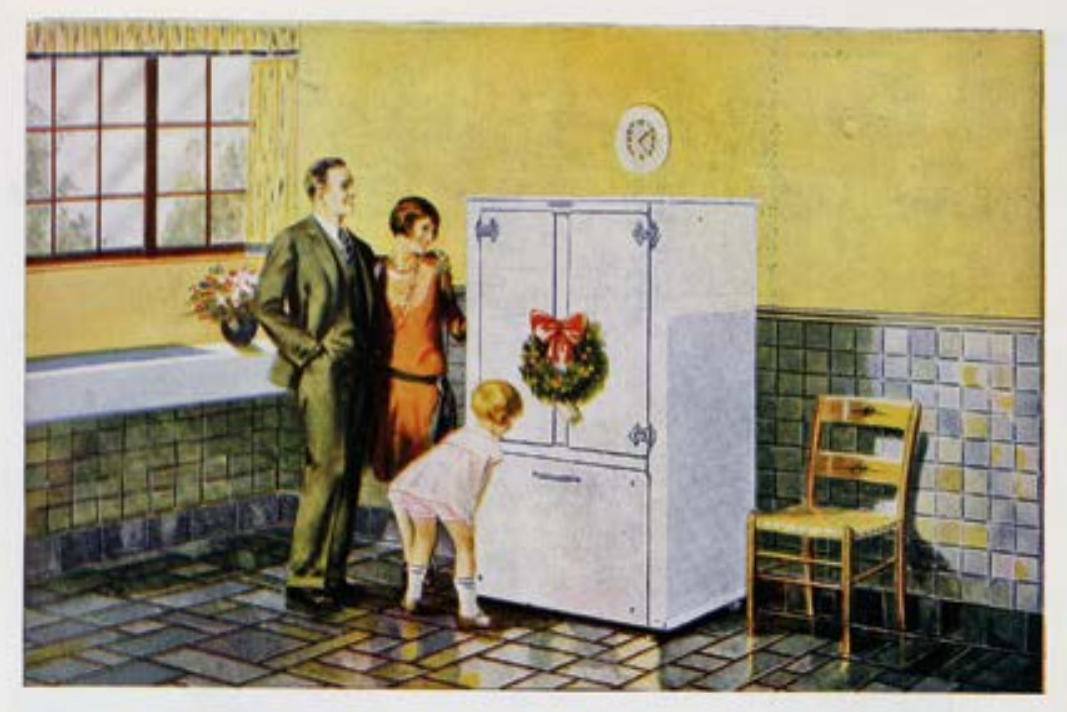

LET FRIGIDAIRE ADD TO YOUR PLEASURE THIS CHRISTMAS
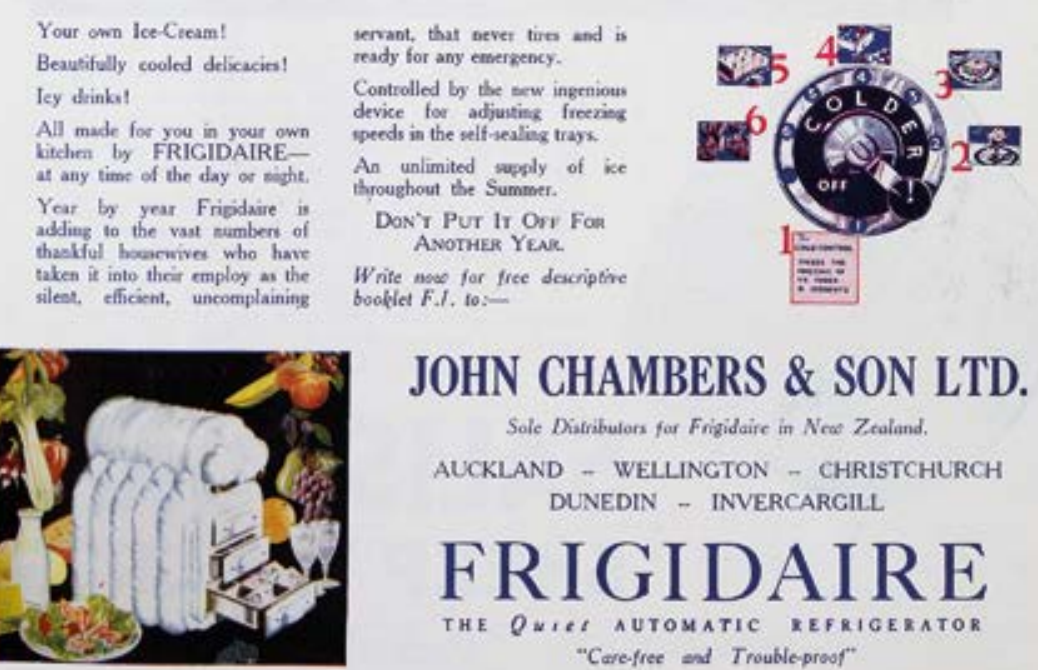

JOHN CHAMBERS \& SON LTD.

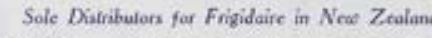
AUCKLAND - WELLINGTON - CHRISTCHURCH DUNEDIN - INVERCARGILL

FRIGIDAIRE THE QNICE AUTOMATIC EEFRIGERATOR

The Mirror

The Mirror began life in 1922 as The Ladies' Mirror: The Fashionable Ladies' Journal of New Zealand. Although successful, a year later it was acquired by one of the original investors and an Auckland entrepreneur, Henry Kelliher. Kelliher assumed the editorship in 1930, the same year he acquired an interest in the brewery that launched his career as one of the country's 'beer barons'. The magazine was aimed at an affluent middleclass reader. At its peak, it had a circulation of about 25,000 copies. It was published until 1963 when it closed during the rebuilding of its printing works and - in the face of stiff competition - did not reappear. 
Zealand Woman's Weekly in the first week of December 1932. The Woman's Weekly (NZWW) was the brainchild of Otto Williams, a former editor of the Mirror (New Zealand's top-selling home journal), and a freelance writer named Audrey Argall, who ran a nursing home in Paeroa. They had a shoestring budget and operated from a single room in the Colonial Mutual Life Building in Auckland's Queen Street. ${ }^{1}$

They were taking a significant risk. The Great Depression was at its height. Their publication would be the first weekly magazine to target the country's female population. And they could not match the aesthetics and production values of the monthly Mirror, which had a strong hold on the market. It was a market that internationally was in a state of change as the role of women as consumers and domestic decision-makers became increasingly evident.

Less than two months before the launch of the NZWW, one of Britain's largest magazine publishers, George Newnes Ltd launched the weekly Woman's Own as "the home paper that realises that any girl worth her salt wants to be the best housewife ever - and then some". It became an immediate success. Cynthia White's study of women's magazines from 1693 to 1968 noted that the arrival of such magazines marked the reorientation of women's journalism away from the servant-keeping leisured classes and toward the middle ranks and, in the case of Woman's Own, to the lower middle ranks serving readers with little or no outside help and a need for advice on both personal and practical matters. ${ }^{2}$

Six months after the NZWW made its appearance, Frank Packer launched the Australian Women's Weekly in Sydney as a magazine to occupy idle time on his presses. It took a different approach, treating women's issues as news rather than merely as matters of domestic routine. ${ }^{3}$

The year 1932 was, according to John Mulgan, when the Great Depression settled on the New Zealand people 'like a new and unwanted stranger, a grey and ghastly visitor to the house'.4 The number of registered unemployed had reached 78,000 and in seven months the Auckland City Mission provided 37,000 beds and 102,800 meals. ${ }^{5}$ Tony Simpson in The Sugarbag Years says this "illdefined monster" cast a long shadow. It was "a blight on everything it touched". ${ }^{6}$ A report in the Auckland Star on the day the Weekly was launched spoke of social workers seeing "semi-starvation, often amid illness, obviously due to malnutrition".7 'Registered unemployed' was a misleading term. Keith Rankin estimates that by 1933 there were 240,000 fully or partially unemployed people in the New Zealand workforce. Furthermore, there were 240,000 people with incomes above zero, but less than $£ 1$ per week, at a time when an adequate living wage was in excess of $£ 4$ per week.

There were few safety nets. Matthew Wright notes that New Zealand's history to this point had been one of minimal welfarism. $\mathrm{He}$ believes this was due, in part, to a 'green fields' colonial attitude that determined that even Britain's inadequate social support systems were unnecessary here. ${ }^{4}$ As a result, when the effects of the depression bit deep, there was an affirmation of traditional values of individualism and community cohesion ${ }^{9}$ - those in adversity had to make the best of things. It was, nonetheless a period of rising dissent that had its most obvious expression in street riots in Auckland, Wellington and Christchurch. ${ }^{10}$ In 1935 a Labour government, intent on a broad agenda of reform, was elected in a landslide.

However, the Great Depression was not an unmitigated disaster for all New Zealanders. Tom Brooking, with a degree of understatement, describes it as "an uneven experience". Despite chronically high unemployment, the demand for consumer goods continued unabated and sales of electric stoves and electric water heating - indicators of the modernisation that was growing in the interwar years - continued to rise. ${ }^{11}$ Michael King has noted that there were some whose occupation or private income meant they scarcely noticed its passage. ${ }^{12}$ Keith Sinclair recorded that some relief gangs were put to work making golf courses ${ }^{13}$ and this author's own father earned more than his foundry worker father by caddying on an Auckland golf course during the depression. Rankin estimates that in 1933 there were almost 67,000 men whose income fell into the 'high' category of more than $£ 260$ a year.

British colonisation of New Zealand may not have brought with it the rigid British class system but the egalitarianism celebrated in the young country was as much myth as reality. There were stratifications that are often overlooked in scholarship that concentrates on the rising power and affluence of the working class. In fact, Nolan notes that underclasses - economic, female and Māori, "have long been part of the New Zealand which slipped through the nets of arbitration, welfare and employment systems". ${ }^{14}$ The distinction was already evident in the pages of The Weekly News, whose pictorial supplements in 1932 juxtaposed coverage of the metropolitan riots and unemployment relief camps with the pictures of fashionable ladies attending the Wellington Racing Club carnival at Trentham and a fashion shoot of beach pyjamas, the 'popular vogue at the seaside'. ${ }^{15}$ As the New 
Zealand Woman's Weekly joined The Weekly News and the Mirror on the newsstands, it was easy to identify the destitute, the poor working class, the middle class and the wealthy in 'egalitarian' New Zealand.

Internationally, magazine publishers came to recognise two distinct markets: The affluent who did not wish to be reminded of the afflictions of the have-nots, and those determined to make the best of what little they had. In Britain, George Newnes Ltd published Country Life for the former and Women's Own for the latter. In Germany, Die Dame (The Lady) commanded the fashionable end the market while Das Blatt der Hausfrau (Housewife's Journal) concentrated on practical domesticity.

On 8 December, 1932, the NZWW carried advertisements for Clever Mary (the enemy of grease) and Creamoata rolled oats while the Mirror suggested a Frigidaire refrigerator for Christmas or a new Austin Ten-Four family car. There was little doubt about where they sat or that the New Zealand market was a reflection of developments further afield. Both were part of a growing ideology of domesticallyoriented consumerism that encouraged women of all social classes to see the home in a new professional light that was closely tied to purchaser influence and decision-making. ${ }^{16}$ Each magazine, however, had a clear perception of the limits of its readers' purchasing power.

Recognition of women as skilled managers of their homes also was part of a wider feminist movement and such magazines - to varying degrees - acknowledged that a woman's destiny may not be only matrimonial and parental.

Much women's magazine scholarship concentrates on feminist studies, arguing that women's magazines are manipulative and contribute to the media's reinforcement of gender differences and inequalities. Some scholars see the apparent 'helpfulness' of women's magazines as superficial and, in fact, reinforcing the oppressed status of women. The harmful construction of 'femininity' in such magazines has been a focus of research from Betty Friedan's seminal book The Feminine Mystique onward. Socio-cultural research on body image has placed women's magazines squarely in the frame- even if the sum of findings on that particular subject points to complexity rather than definitive cause and effect. ${ }^{17}$

Ethnographic studies by Joke Hermes suggest women's magazines need to be seen within the context of 'everyday talk' which is non-reflective, pragmatic and used to explain or justify. She cautions against confusing the media critic with the ordinary reader. ${ }^{18}$ Hermes believes media use is 'a fleeting, transient experience that doesn't leave much trace in how everyday practices are structured'. This view of magazine readership is supported by Todd Gitlin who describes magazines as 'a limited liability experience' that provided 'low-risk access to a bountiful world'. ${ }^{19}$

Nonetheless, Anna Gough-Yates makes a persuasive argument that analysis of magazines at the latter part of the 20th century shows how cultural discourses around particular forms of feminine identity were a crucial factor in determining their form. ${ }^{20}$ It is a conclusion that can equally be drawn from a study of the impact of modernity on the status and aspirations of women in the interwar years. ${ }^{21}$ Historiographic studies - tracing the development of women's magazines through this period of social and economic change including the rise of consumerism, the women's movement and feminism, changing patterns of media consumption and so on - testify to women's magazines reflecting socio-cultural change as much as the profound effect that the Great Depression had on their stratification and reorientation.

Women's magazines in the 1930 s were a sometimes-

incongruous amalgam. More than 80 years later, our task of analysing and understanding them is made easier if we keep an historical frame of reference. ${ }^{22}$ Rather than applying a 21 st century lens, if we place ourselves in that period of socio-economic turmoil that lasted from the end of one world war to the start of the next, we are better able to explain some of these incongruities and use these two publications to illustrate how they were manifested.

This was a transitional age in which the traditional perceptions of the role of women were being contested by a more enlightened and emancipated view of womanhood that challenged an overtly and largely uncontested patriarchal society. On the one hand, women's magazines of the time championed the very domesticity that kept women in the home while, at the same time, offering tantalizing insights into the possibilities that awaited those who broke the chains. For those whose destiny (chosen or otherwise) was to be a homemaker the magazines offered a different form of escape. They took their readers to the fashion salons of Paris and transported them into the fictional world of short stories and serials.

Social status, on the other hand, was only too well delineated by the two magazines. The first issue of the NZWW looked like the affluent Mirror's poor cousin even though the weekly's cover price of $3 \mathrm{~d}$ aggregated to the monthly's one shilling. Its purple monochrome cover with a crudely clear-cut image of a woman modelling a lace 
jumper ("full instructions on page 19") was accompanied by a series of nondescript cover lines and a strap-line telling potential readers "don't miss first instalment of absorbing serial story" without giving the slightest hint of its subject. It was a no-nonsense, practical cover that would appeal to the woman who had to watch her pennies. In stark contrast, the cover of the Mirror was a striking colour picture of a mountain peak with a young Māori girl paddling a canoe in the foreground. It was the work of Leonard Cornwall Mitchell (1901-1971), one of the period's most accomplished poster painters. His work for the Tourist Department produced some of New Zealand's most memorable scenic posters and the iconic imagery that advertised the New Zealand Centennial Exhibition in Wellington in $1939 .{ }^{23}$ This cover spoke of an untroubled land.

The Weekly's title page carried a well-wishing letter from the Prime Minister, George Forbes, that acknowledged "a large share of the troubles arising out of the strenuous and anxious times through which the world is presently passing falls on the shoulders of our women". An unsigned introduction (most likely penned by co-owner Otto Williams) made no mention of the depressed state of the economy and took an upbeat approach that would "preach the gospel of usefulness, cheerfulness and happiness". Nor did Audrey Argall's editorial introduction acknowledge dark days, although her description of future content suggests she was aware that many of her readers would expect considerable value for what the introduction described as "the trifling sum of threepence".

The editorial in the Mirror, on the other hand, was a serious doctrinaire essay on the folly of unrestrained monetary credit. The magazine's editor (and owner) was Henry Kelliher, later to become a knight and New Zealand's archetypal beer baron as chairman of Dominion Breweries. Kelliher was a champion of Douglas Social Credit - which gained some currency in the 1920s and 1930s - and used the Mirror to promote his views on monetary reform. ${ }^{24} \mathrm{He}$ had strong ideas about how New Zealand could extricate itself from The Slump and his editorial warned that failure to heed his words would result in "a lowering of the standard of living and physical and moral degradation," to say nothing of civil unrest.

The pages of both magazines reveal vastly different production qualities. The Mirror was lavishly illustrated with full-page half-tone photographic images, photographic spreads and a colour supplement. The NZWW appeared to have been produced on a tired monochrome sheet-fed press that left variable type impressions on the page.
Photographs were limited to head-and-shoulder portraits and the majority of illustrations were line drawings and stock typographical decorations. While the Mirror's accomplished design and lavish illustration left a graphic impression, the Weekly had a strong but unimaginative reliance on the printed word.

The new magazine did, however, have a strongly feminine look that stood in marked contrast to the Mirror's passing regard for its female readership. Kelliher played little part in the production of the magazine. That was left to his deputy, Oliver Gillespie, a decorated First World War officer, who produced a magazine that had more in common with The Weekly News or New Zealand Free Lance than with contemporary women's magazines. The December issue, for example, contained illustrated articles on the importance of shipping services, the strange behaviour of seabirds, and Winston Churchill's assessment of the effects of Prohibition in the United States (he was not a supporter).

There were common elements in both magazines, notably in their approach to fiction. They contained almost equal amounts of fiction (14 pages in the NZWW and 15 pages in the Mirror) although the newcomer set a new standard with the content it acquired. Its romantic short story offerings included work by Everett R. Castle (a widelysyndicated writer) and Ivor Brown (later editor of London's Observer). It contained a mystery story by A.J. Alan, the pseudonym of Leslie Harrison Lambert, a well-known BBC broadcaster and short story writer who was also a British intelligence officer and later a senior codebreaker at Bletchley Park in the Second World War. However, the fiction coup for the Weekly was that "first instalment of absorbing serial story" announced on the cover. It was 'The City of Stones', a desert romance by E.M. Hull who was the author of The Sheikh. That novel had been adapted into a film starring Rudolph Valentino and, along with a sequel, had enjoyed "extraordinary showings" throughout New Zealand in the 1920s. ${ }^{25}$ The centre-piece serial in the Mirror was 'Evensong' about the life of an opera singer. Its author was Beverly Nichols, an eclectic writer at the beginning of his career. He had been Dame Nellie Melba's private secretary and, although it was not known at the time, the story may have been based on aspects of her life.

The first Weekly contained no locally-written fiction although it did publish an article on women's right to choose a business career ${ }^{26}$ by Auckland journalist Isabel M. Cluett (Isobel Maud Peacocke) who contributed fiction and non-fiction to magazines including the Mirror. Distinctive New Zealand fiction was beginning to emerge from the pens of writers such as Frank Sargeson and Robin Hyde. The Mirror published 
the work of New Zealand writers but tended to select material that reflected the middle-class values of its audience and few of these writers rose to prominence. ${ }^{27}$ The Weekly's weak financial position in its formative stage saw it lean more toward cheaper overseas syndication, although it later published material by New Zealand authors such as Hyde. While pushing boundaries, the tone of these contributions was moderate. More radical contributions by women appeared in Working Woman and later in the short-lived Woman Today-edited by Elsie Freeman (Locke) and with contributions from writers such as Robyn Hyde and Jessie Mackay. Its three-year life abruptly ended with the outbreak of the Second World War.

Overall, the fiction in both magazines had a distinctly English tone that also permeated other parts of the magazines. In the case of the Mirror, the tone reinforced its middle-class appeal which was also supplemented by social pages with a marked Vice-Regal element and pages of photographic studio portraits of the well-to-do and their children. Its Christmas cooking pages assumed the reader could pay for turkey, goose, "boar's head", rum punch and Christmas pudding with brandy sauce. The NZWW, in contrast, told its readers that Christmas would be incomplete without a cake "however plain or fancy the cake might be" although it, too, may have been aiming a little high in suggesting that "the average housewife keeps the cake and biscuit tins always well stocked". Generally speaking, the Weekly's centre pages cooking section ("easily detached and kept by readers for future reference") were based on low-cost ingredients.

The contrast between fashion coverage in the respective magazines was even more marked. While the NZWW emphasis was on making clothes and making-do, the Mirror impressed its readers with Linda Anivitti's fashion despatch from Paris, in which she casually let drop that the previous week she had gone to the Riviera to see the latest in holiday fashions. The Weekly's readers made do with line drawings of frocks and children's clothing but the Mirror enhanced its notes on the "chic Parisienne" with fashion photographs.

The period between the wars saw a rising interest in female fitness, either as an adjunct to the young, fashionable image first symbolised by 'the flapper' of 'the roaring twenties' or as part of a realisation by women of their 'inner selves'. ${ }^{28}$ The December issue of the Mirror featured fitness as an aid to beauty while the NZWW emphasised the wellbeing benefits of keeping fit. The weekly's editor made a clever choice of writer. Australian Annette Kellerman was not only internationally-known as a lecturer and writer on women's fitness but was also a swimming star and Hollywood actress who had appeared in the movie Venus of the South Seas, a popular US-New Zealand coproduction shot in Nelson in 1924. ${ }^{29}$

Although the Mirror contained articles on 'homemaking'- and in spite of its claim to be "the home journal of New Zealand" - the emphasis was elsewhere. Only 14 of its 90 pages were devoted to home and family and generally supposed a level of affluence. By contrast, after providing women with a figurative escape from the realities of the depression, the second half of the first issue of the NZWW was devoted to helping women run their households and care for their children.

Twenty of its pages covered aspects of life in households with tightened belts, beginning with 'These Hard Times' and ideas for using old sugar bags (more creatively than was the case in Tony Simpson's The Sugar Bag Years, where they were characterised as a carry-all and raincoat for the unemployed).

The times were indeed hard and no less so than for the Weekly itself. Its first issue of 66 pages carried the equivalent of only 11 pages of advertising compared to 33 pages in the Mirror's 90-page edition - a ratio of 16.6 per cent advertising against 36.6 per cent in the Mirror. By its fourth week, the NZWW carried the equivalent of 14 pages of advertising but the size of the magazine had been reduced to 54 pages. After three months, the Woman's Weekly Publishing Company ran out of money and Williams sold the title to Ellen Melville, an Auckland lawyer and women's rights activist. A further year, and two more owners later, it was sold to the proprietors of the Auckland Star. Nevertheless the poor cousin outlasted the Mirror, which closed in 1963 and in 1977 became the largest selling women's magazine per head of population in the world. ${ }^{30}$

The December 1932 editions of the NZWW and The Mirror provide clear illustrations of the socio-economic stratification of consumer magazines that was becoming apparent in the interwar years. Cheap, mass circulation weekly magazines for less-affluent female readers filled a market gap and did not challenge the position of monthly periodicals aimed at the affluent middle class. The NZWW stated in its first issue that it was to 'cater for all of the people, irrespective of class, creed, age, or social standing' but each successive page points to that market gap. Even the titles suggested market differentiation. There was the Woman's Weekly but The Mirror was The Ladies' Mirror long after its title was foreshortened.

These issues also support cultural production theories 
of identity and the methods employed by magazines to shape relationships with their readers for both commercial and cultural reasons. The NZWW, for example, acknowledged attempts by the less-affluent woman to emerge from the restrictive stereotypes of domesticity but seamlessly allowed this to co-exist with the pragmatic demands of domestic life in the Great Depression. Audrey Argall was a working woman who saw no inconsistencies between stories on career aspiration and home management that required intelligence and skill. Even in its first edition the magazine signalled that it understood its readers at an almost personal level. The Mirror, on the other hands, equated the gender of its readership with status and wealth. Henry Kelliher was a businessman on the rise and his deputy a journalist of the old school. They and their magazine had the New Zealand Establishment writ large: the relationship with the reader was one of comfort and security, perhaps even cosy detachment from harsh realities.

Magazines mirror culture, they do not create it. ${ }^{31}$ They have provided rich sources for research on social and cultural change. However, no single issue of a women's magazine can provide an accurate picture of social reality. Perhaps no single women's magazine can do so. The purpose of the comparison presented here has been to demonstrate that the social, cultural and commercial distinctions which emerged in the New Zealand magazine market were obvious from the first issue of the Woman's Weekly. Alongside The Mirror, its cover cried poor for a reason that went well beyond the meagre capita of its founders.

\section{REFERENCES}

Alsop, Peter, Gary Stewart \& Dave Bamford (eds.), Selling the Dream: The art of early New Zealand tourism. Nelson: Craig Potton, 2012

Barnett, Stephen. Those were the Days: A nostalIy News. Auckland: Moa Publications, 1987.

Brookes, Barbara. A History of New Zealand Women. Wellington: Bridget Williams Books, 2016 Dittmar, Helga. “How do 'Body Perfect' Ideals in the Media Have a Negative Impact on Body Image and Behaviors? - Factors and processes related to self and identity." Journal of Social and Clinical Psychology 28, no.1 (2009): 1-8.

Gibbons, P.J. "The Climate of Opinion" in Oxford History of New Zealand Second Edition edite by Geoffrey W. Rice. Auckland: Oxfo Press, 1992, 302-332.

Gitlin, Todd. Media Unlimited. New York: Ow Books, 2002

Gough-Yates, Anna. Understanding Women's Magazines: Publishing, Markets, Readerships. London: Routledge, 2003

Greenfield, Jill \& Chris Reid. "Women's magazines and the commercial orchestration of femininity in the 1930s: Evidence from Woman's Own", Media History 4, no.2 (1998) 161-174.

Hermes, Joke. "Media, Meaning and Everyday Life" in Cultural Studies 7, no. 3 (1993) 493-506.

King, Michael. Penguin History of New Zealand. Auckland: Penguin, 2003

Lynch, Jenny \& Joy McDougall in Janet Blackwe (ed) Woman's Weekly: The First 60 Years. Auckland: Moa Beckett, 1992.

Macdonald, Charlotte. "Body and Self: Learning to be modern in 1920s-1930s Britain", in Women History Review 22, no.2 (2013): 267-279.
Mulgan, John. Report on Experience. Wellington: Victoria University Press, 2010.

Nolan, Melanie. "The Reality and Myth of New Zealand Egalitarianism: Explaining the Pattern of a Labour Historiography at the Edge of Empires", Labour History Review 72, no.2 (2007): 113-134.

O'Brien, Denis. The Weekly. Ringwood (Vic): Penguin, 1982

Olssen, Erik. "Towards a New Society" in Oxford History of New Zealand Second Edition edited by Geoffrey W. Rice. Auckland: Oxford University Press (1992): 254-284.

Rankin, Keith. "Unemployment in New Zealand at the Peak of the Great Depression", a pape presented to the 1994 Conference of the Ecopresic History Association of Australia and Premic History Association of Aus tralia and New Zealand. Retrieved from http://keithrankin.co.nz/ NZunem1933/

Sinclair, Keith. A History New Zealand. Auckland: Penguin, 2000.

Sumner, David E. The Magazine Century: American magazines since 1900. New York: Peter Lang 2010

White, Cynthia L. Women's Magazines 1693-1968. London: Michael Joseph, 1970.

Wright, Matthew. "Mordacious Years: Socio-economic aspects and outcomes of New Zealand's experience in the Great Depression" in Reserve Bank of New Zealand Bulletin, 72, No. 3, September 2009. 


\section{ENDNOTES}

1 Jenny Lynch \& Joy McDougall in Janet Blackwell (ed) Woman's Weekly: The First 60 Years. Auckland: Moa Beckett, 1992, p. 6 .

2 Cynthia L. White, Women's Magazines 1693 1968. London: Michael Joseph, 1970, p.96.

3 Denis O'Brien, The Weekly. Ringwood (Vic): Penguin, 1982, p. 6.

4 John Mulgan, Report on Experience. Welling ton: Victoria University Press, 2010 [Kindle edition, Chapter 1].

5 Matthew Wright, "Mordacious Years: socio-economic aspects and outcomes of $\mathrm{New}$ Zealand's experience in the great Depression in Reserve Bank of New Zealand Bulletin, Vol 72, No. 3 September 2009, p. 50

6 Tony Simpson, The Sugarbag Years: An oral history of the 1930s depression in New Zealand. Wellington: Alister Taylor Publishing, 2012, pp. 5-6.

7 Auckland Star, 8 December 1932, p.9.

8 Keith Rankin, "Unemployment in New Zealand at the Peak of the Great Depression", a paper presented to the 1994 Conference of the Economic History Association of Australia and New Zealand. Retrieved from http:// keithrankin.co.nz/NZunem1933/

9 Erik Olssen, "Towards a New Society" in Oxford History of New Zealand Second Edition edited by Geoffrey W. Rice. Auckland: Oxford University Press, 1992, p.281

10 P.J. Gibbons, "The Climate of Opinion" in Oxford History of New Zealand Second Edition edited by Geoffrey W. Rice. Auckland: Oxford University Press, 1992, p.328.

11 Tom Brooking, "Economic Transformation", in Oxford History of New Zealand Second Edition edited by Geoffrey W. Rice. Auckland: Oxford University Press, 1992, p. 251.

12 Michael King, Penguin History of New Zealand. Auckland: Penguin, 2003, p. 349.

13 Keith Sinclair, A History New Zealand. Auckland: Penguin, 2000, p.266.

14 Melanie Nolan, "The Reality and Myth of New Zealand Egalitarianism: Explaining the Pattern of a Labour Historiography at the Edge of Empires", Labour History Review, 72:2, p. 120.

15 Stephen Barnett, Those were the Days: A nostalgic look at the 1930s from the pages of The
Weekly News. Auckland: Moa Publications, 1987, pp.61-74.

16 Jill Greenfield \& Chris Reid (1998) “Women's magazines and the commercial orchestration of femininity in the 1930s: Evidence from Woman's Own", Media History, 4:2, 161-174,

17 Helga Dittmar, "How do 'Body Perfect' Ideals in the Media Have a Negative Impact on Body Image and Behaviors? - Factors and processI related to self and identity" in Journal of Social and Clinical Psychology, 28:1, 2009, Pp. Socialand Clinical Psychology, 28:1, 2009, $P$. $1-8$

18 Joke Hermes, "Media, Meaning and Everyday Life" in Cultural Studies 7:3, p. 504.

19 Todd Gitlin, Media Unlimited. New York: Owl Books, 2002, p. 50

20 Anna Gough-Yates, Understanding Women's Magazines: Publishing, Markets, Readerships. London: Routledge, 2003, p.21.

21 See, for example, Chapter 8 (The 'Modern Woman' of the Interwar Years) in Barbara Brookes' A History of New Zealand Women. Wellington: Bridget Williams Books, 2016, pp. 218-255.

22 Tim Holmes and Liz Nice provide a persuasive overview of approaches to magazine field theory in Chapter 7 of Magazine Journalism. London: Sage, 2012.

23 Peter Alsop, Gary Stewart \& Dave Bamford (eds.), Selling the Dream: The art of early New Zealand tourism. Nelson: Craig Potton, 2012.

24 While Social Credit would take on the characteristics of a fringe party after its formation in 1953, the economic theories of Major C.H. Douglas attracted widespread interest in the 1920s and 1930s. Keith Sinclair (ibid. pp. 2734) said members of the Labour Party 'flirted with Douglas Social Credit - not always discreetly' in the lead-up to the 1935 election.

25 Evening Post, 5 April 1922, P. 3.

26 The Mirror's recognition of the career woman was not by-lined (yet pock-marked by personal pronouns) article on page 53 about the Wellington-based owner of a group of fashion salons, Mary Garden.

27 The Mirror regularly carried a page of answers to correspondents who had submitted manuscripts. The responses ranged from ncouragement to mercy killing. Examples from the December issue: Knitting (IED, Masterton): Distinct improvement. Carry on; My Garden (MM, Foxton): We advise you to study the technique of the art of writing before producing further efforts; My Ships of Simple Secrets (TT, Morrinsville): Wrecked on the rocks of ruthless re-editing. In 1933, Frank Sargeson received the following rejection of a short story: 'Very fair. Marred by an overdose of up-to-date slang. Make your dialogue more convincing'. In a 1996 doctoral thesis "New Zealand English Language Periodicals of Literary Interest Active 1920s-1960s", Stephen Hamilton noted that the Mirror printed work by an enormous number of New Zealand's amateur and serious poets and short story writers but the popular nature of most of the material published has excluded of the material published has excluded many of its authors from inclusion in the generally accepted canon of New Zealand literature.
28 Charlotte Macdonald, "Body and Self: Learning to be modern in 1920s-1930s Britain", in Women's History Review, 22:2 2013, pp. 267279

29 Venus of the South Seas featured Kellerman who also wrote the script, as a pearl diver. Parts of the movie were filmed underwate and one reel was shot in Prisma Color. The movie was one of the last shot using the process, which was overtaken by Technocoprocess, which was overtaken by Technocolor [IMDb]. Kellerman had earlier gained a certain notoriety by becoming the first major actress to appear nude on film (A Daughter of the Gods, 1916)

30 Jean Wishart, NZWW, 24 October 1977.

1900. New American magazines since Peter Lang, 2010, p. 13. 